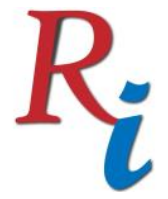

Asia Proceedings of Social Sciences

(APSS)

www.readersinsight.net/APSS

\title{
SPEECH PERCEPTION AND PRODUCTION OF VOICING IN THAI NATIVE SPEAKERS USING ENGLISH AS FOREIGN LANGUAGE
}

\section{Panornuang Sudasna Na Ayudhya*}

Research and Development Institute, and Faculty of Humanities and Social Sciences

Bansomdejchaopraya Rajabhat University

Thailand

panor.sudas@gmail.com

*Corrosponding author's Email: panor.sudas@gmail.com

Peer-review under responsibility of $5 t^{d}{ }^{d}$ Asia International Conference 2019 Scientific Committee

http://connectingasia.org/scientific-committee/

(C) 2019 Published by Readers Insight Publisher,

lat 306 Savoy Residencia, Block 3 F11/1,44000 Islamabad. Pakistan,

editor@readersinsight.net

This is an open access article under the CC BY-NC-ND license (http://creativecommons.org/licenses/by-nc-nd/4.0/). 


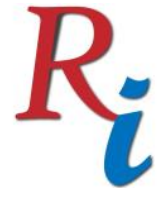

Asia Proceedings of Social Sciences

(APSS)

www.readersinsight.net/APSS

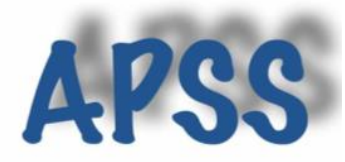

\section{A b s tract}

The study is aimed to discuss the two notions of relationship between speech perception and production. These two notions are perception precedes production or vice-versa. The notion of perception precedes production proposes that production of a new sound must follow the success of perception of this sound (Polivanov, 1931). Whereas, the notion of production precedes perception proposes that there are certain situations, in which perception of a new sound must follow the success of production of this sound (Neufeld, 1988; Borrell, 1990). This paper also illustrates the evidences obtained from the experiment of the perception and production of voiced and voiceless English sounds in 200 Thai native speakers. The results reveal the analysis of errors, which illustrated the relationship of speech perception and production.

Keywords: Perception, Production, Voiced, Voiceless

\section{Rese a r ch High Iights}

The data of error analysis obtained from the perception experiment revealed that there was a main effect for different types of voicing perception in two groups of subjects with high and low English language skill.

The data of correct production scores obtained from the production experiment illustrated that English voiceless sounds obtained higher mean correct production scores than English voiced sounds did in both two groups of subjects with high and low English language skill.

The results of the experimental evidences revealed that there is a distinguished relationship between foreign language perception and production and this relationship is influenced from the level of foreign language skills.

\section{Research Objectives}

1. To investigate the perception of voiced and voiceless English sounds in Thai native speakers with high and low English skills. 


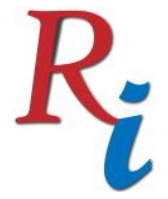

\section{Asia Proceedings of Social Sciences}

(APSS)

www.readersinsight.net/APSS

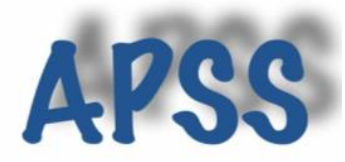

2. To investigate the production of voiced and voiceless English sounds in Thai native speakers with high and low English skills.

3. To study the relationshop between the perception and the production of voiced and voiceless English sounds in Thai native speakers with high and low English skills.

\section{Methodology}

200 Thai native speakers using English as foreign language were selected. The subjects were classified as two groups based on their English language testing scores obtained from an English course in a university. The result instruments consist of perception task and production task. The perception task included 100 pairs of words, which half of items are begun with voiced sounds and another half of items is begun with voiceless sounds. The subjects were asked to respond to these items. The production task includes 100 words, which half of items are begun with voiced sounds and another half of items is begun with voiceless sounds. The subjects were asked to pronounce these words. The pronunciation was evaluated by three native speakers. The data obtained from perception and production tasks were analyzed using Two-way ANOVA.

\section{Results}

According to the perception task, the results revealed that there was a main effect for different types of voicing perception in High group $\mathrm{F}(1,123)=19.51, \mathrm{p}<.05$ and in Low group $\mathrm{F}(1,123)=25.85, \mathrm{p}<.05$.

According to the production task, English voiceless sounds obtained higher mean correct production scores than English voiced sounds did in both two groups of subjects with high and low English language skill.

\section{Findings}

The results of the experimental evidences revealed that there is a distinguished relationship between foreign language perception and production and this relationship is influenced from the level of foreign language skills. 


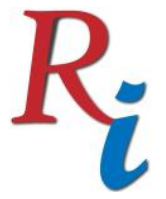

Asia Proceedings of Social Sciences

(APSS)

www.readersinsight.net/APSS

\section{References}

Borrell, A. (1990). Perception et (re)production dans l'apprentissage des langues étrangères. Quelques réflexions sur les aspects phonético-phonologiques. Revue de phonetique applique, 95, 107-114.

Neufeld, G.G. (1988). Phonological asymmetry in second language learning and performance. Language learning, 38 (4), 531-559

Polivanov, E. (1931) La perception des sons d'une langue étrangère Travaux du Cercle Linguistique de Prague 4, 111-14.

Author's Biography

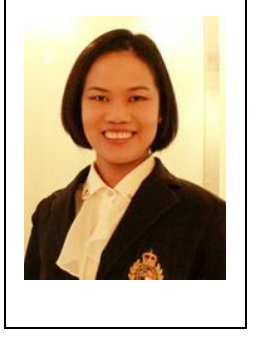

Panornuang Sudasna Na Ayudhya is a lecturer in English at Bansomdejchaopraya Rajabhat University. In 1996, she graduated with first class honor, receiving a B.A. with a double major in English and Psychology, Chulalongkorn University. Then, she was awarded a scholarship from Thailand Research Fund to study Ph.D. in Linguistics at Chulalongkorn University and graduated in 2002. 